\title{
RADICAL THACITR
}

A SOCIALIST, FEMINIST, AND ANTI-RACIST JOURNAL ON THE THEORY AND PRACTICE OF TEACHING

\section{Black Lives Matter in Information Literacy}

(RADICAL TEACHER NO.106, 2016)

by Angela Pashia

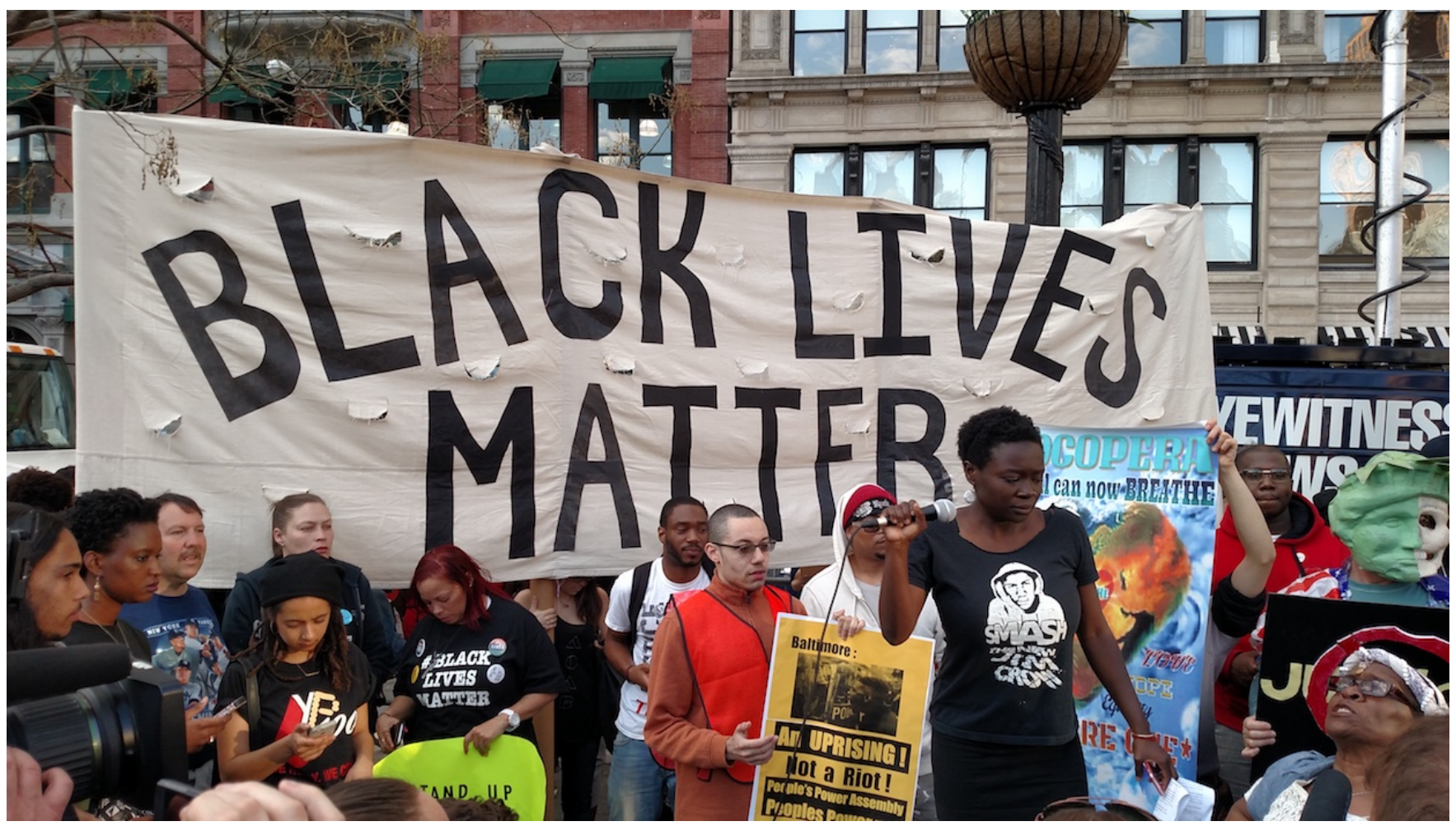


$\mathrm{F}$ or many academic librarians, teaching information literacy is a core component of librarianship. Depending on one's institutional context, this can happen in one-on-one interactions at a reference desk, in course-integrated instruction sessions (in which a librarian visits a class to teach students about finding credible sources for a term paper), and/or in a creditbearing course.

Most people think of librarians teaching students to access books or articles, but information literacy involves much more. The Association for College \& Research Libraries (ACRL) defines it as "the set of integrated abilities encompassing the reflective discovery of information, the understanding of how information is produced and valued, and the use of information in creating new knowledge and participating ethically in communities of learning" (ACRL 2015). This can be taught as a "neutral" practice. For example, we can teach students to evaluate information sources according to a simple checklist, usually including the authority (often focused on formal credentials) of the author, publication date, and purpose of the piece, without having to examine the power structures that enabled that author to become an authority or the ideological biases represented in the piece.

Critical information literacy (CIL) pushes us to raise the questions that get left out of that "neutral" approach. CIL asks practitioners to acknowledge that the range of information available, the learners, and those teaching information literacy are all socially situated entities. It is important to teach the ways in which "the existing information system mirrors the larger social and political order, which is characterized by a radically asymmetrical distribution of power, and is shot through, systematically and structurally, by racism, sexism, homophobia, militarism, and class oppression" (Beilin 2015). From this perspective, teaching Black Lives Matter should be a component of information literacy.

At the University of West Georgia, I teach a course titled "Information Literacy and Research." The course is not required, but it is included as one of the electives students may take to fill a core curriculum requirement. It covers a range of topics related to library-based research, including how to find, access, and evaluate appropriate information sources and how to use that information ethically. I employ CIL by encouraging students to examine the power structures involved in all of the concepts we discuss. I set the stage for this on the second day of class with a lesson that asks students to think critically about the university itself, and how that affects everything else that we will discuss throughout the semester.

We begin by watching a video posted on the University College of London's YouTube channel: "Why is my curriculum white?" (UCLTV 2014). This 20-minute video features students questioning the whiteness of the established canon in their respective fields, asking why more non-white and non-Western scholars are not included in the curriculum, and discussing the effects of that exclusion on themselves and their perceptions of academia.

After we watch this video, I ask students to search online for the demographic profile of students and faculty at our university. Our student body is $53.2 \%$ white and $36.0 \%$ black/African American, while our faculty are $81.4 \%$ white and only $6.6 \%$ black/African American (UWG 2016). Most very quickly find data reported on various websites. After the students have a few minutes to search, I ask for a volunteer to share the website they found on the instructor computer. This opens a range of discussion topics for the remainder of the session: evaluating the reliability of the sites they found, asking where those sites are pulling their data from, and discussing why any of this matters in a class about library research.

Drawing connections between this video, the demographics of our university, and information literacy leads to questions about how we construct authority and what information gets left out of those constructions. Examining the authority of the creator of an information source is generally an important part in determining whether a source is credible. This makes sense, given that we do not want students citing just anyone who posts to the internet with a lot of opinions but no real expertise to support those opinions. Training students to seek out scholarly experts means that they will find information that is well grounded in published research. However, these markers of authority are socially constructed within the context of structures of oppression, including racism and sexism.

Discussions of scholarly authority, especially in the context of topics like the Black Lives Matter movement, need to also address the structures of racism and sexism that have been deeply woven into the foundations of academia and scholarly publications. When we examine the traits that distinguish a scholarly publication from a non-academic source, students learn that scholarly sources are generally written by people who hold the terminal degree in their field and have university affiliations. What does it then mean for the students' evaluation of those scholarly sources if they also consider that, based on data from fall $2013,79 \%$ of "all full-time faculty in degree-granting postsecondary institutions" were white (NCES 2015)? When students rely entirely on scholarly sources to analyze the Black Lives Matter movement, what voices and perspectives are excluded? This can be countered by seeking out those scholars who intentionally give voice to marginalized informants, but budding researchers do not all inherently recognize the need to look for this. We return to the issues raised in this lesson repeatedly throughout the semester.

I encourage students to critically evaluate all of the information they receive, whether they plan to use it for a term paper or their own personal interests. Though students have received many dismissive messages about the value of social media, it can be a powerful tool for counter-narratives to the hegemonic discourse. As students learn about the information cycle -- differences in the way different types of sources are produced, and the consequent time it takes for 
them to be published -- we discuss how students may research a current topic in the weeks and months after an event. Scholarly sources should be used to provide a foundation for scholarly analysis, but will not yet have been published about that specific event, so the researcher must turn to news reports. The most common way of constructing authority in this instance is to rely on the reputation of established news media sources for reports about the recent event. However, most news organizations are beholden to their parent companies, their advertisers, and the audience those advertisers speak to. This introduces a range of power dynamics that influence the way those news organizations frame a story.

One example I use to illustrate this is a series of tweets from August 11, 2014. At that point, local news networks had begun to report on the "unrest" and "riots" in Ferguson, Missouri, portraying a narrative of unruly mobs getting out of control. And then, a set of tweets re-framed that narrative. One protester posted a series of tweets alleging that the local news crew was filming selectively: not filming calm protests, not filming a car of white teens who rolled through the location shouting racist slurs, but then filming the angry reaction from the predominantly black crowd and broadcasting that as representative of the crowd's behavior. This leads to a discussion of framing, how the details selected for inclusion or exclusion can affect the implicit message of a news report, and how social media can either fill gaps or poke holes in news reports. Of course, selecting credible sources from the flood of tweets on a trending topic is challenging, so we discuss ways to evaluate the credibility of an individual twitter account. This is more work than simply accepting the account posted on CNN based on the authority of an established news network, but it is important for students who want to begin to question the hegemonic narrative. This work of questioning the biases and power dynamics inherent in the production of information is challenging for students. My impression has been that very few of the students I work with have ever been invited to examine or criticize their educations in this way. As you may imagine, some are resistant and others flourish.

I ask students to examine and reflect on these issues through various assignments over the course of the semester. By the end of the course, students are able to describe some of the ways power structures limit the information easily available to them and how they can seek out alternate perspectives. The danger in this, of course, is that questioning these structures may lead some to lend credence to perspectives that lack solid evidence, which is why it is important to emphasize the need to evaluate the evidence and context for those claims. However, encouraging students to be mindful of ways racism influences the production of information, to question dominant narratives, and to include a wider range of perspectives in their research is a small step toward challenging implicit biases and structures of oppression, in order to make sure that Black Lives -- including experiences, stories, and scholarship -- Matter.

\section{References}

Association of College and Research Libraries (ACRL). (2015). "Framework for Information Literacy for Higher Education." Retrieved from http://www.ala.org/acrl/standards/ilframework.

Beilin, I. (2015). "Beyond the threshold: Conformity, resistance, and the ACRL Information Literacy Framework for Higher Education." In the Library with the Lead Pipe. Retrieved from http://www.inthelibrarywiththeleadpipe.org/2015/beyo nd-the-thresholdconformity-resistance-and-the-aclrinformation-literacy-framework-forhigher-education/

NCES: National Center for Education Statistics. (2015). "Fast facts: Race/ethnicity of college faculty." Retrieved from https://nces.ed.gov/fastfacts/display.asp?id $=61$.

UCLTV. (2014). "Why is my curriculum white?" Retrieved from https://youtu.be/Dscx4h2l-Pk.

University of West Georgia (UWG). (2016). 2015 - 2016 Fact Book. Retrieved from https://www.westga.edu/administration/president/iea/ assets/docs/Fact Book_2016_Web.pdf. (c) EY-NC-ND

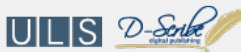

This work is licensed under a Creative Commons Attribution-Noncommercial-No Derivative Works 3.0 United States License.

This journal is published by the University Library System of the University of Pittsburgh as part of its $\underline{\mathrm{D}-S c r i b e}$ Digital Publishing Program, and is cosponsored by the University of Pittsburgh Press.
RADICAL TEACHER 